\title{
Critical Thinking Cognitive Skills and Their Associated Factors in Chinese Community College Students in Hong Kong
}

\author{
Sau-Yee $\mathrm{Ng}^{1}$, Kin Cheung ${ }^{2, *(1)}$ and Hui-Lin Cheng ${ }^{2}$ \\ 1 Division of Science, Engineering \& Health Studies, College of Professional \& Continuing Education, \\ The Hong Kong Polytechnic University, Hong Kong; sally.ng@cpce-polyu.edu.hk \\ 2 School of Nursing, The Hong Kong Polytechnic University, Hong Kong; eileen.cheng@polyu.edu.hk \\ * Correspondence: kin.cheung@polyu.edu.hk
}

check for

updates

Citation: Ng, S.-Y.; Cheung, K.;

Cheng, H.-L. Critical Thinking

Cognitive Skills and Their Associated

Factors in Chinese Community

College Students in Hong Kong.

Sustainability 2022, 14, 1127. https://

doi.org/10.3390/su14031127

Academic Editors: Fermin Sanchez-

Carracedo, Jordi Segalàs Coral and

Gemma Tejedor

Received: 23 December 2021

Accepted: 12 January 2022

Published: 19 January 2022

Publisher's Note: MDPI stays neutral with regard to jurisdictional claims in published maps and institutional affiliations.

Copyright: () 2022 by the authors Licensee MDPI, Basel, Switzerland. This article is an open access article distributed under the terms and conditions of the Creative Commons Attribution (CC BY) license (https:// creativecommons.org/licenses/by/ $4.0 /)$.

\begin{abstract}
The importance of fostering critical thinking (CT) in community college education has been recognized highly worldwide. However, limited studies have been conducted to investigate CT abilities among community college students in the Asian context. A cross-sectional correlational study was conducted with 209 Chinese community college students to assess the levels of CT cognitive skills and CT dispositions and to identify the associated factors. The California Critical Thinking Skills Test (CCTST), California Critical Thinking Disposition Inventory (CCTDI), and a questionnaire on the students' socio-demographic and academic profiles were used. The results showed that the average level of CT cognitive skills was $17.82 \pm 4.10$, which was at the upper end of the moderate range. For CCTDI scores, the mean value was $278.81 \pm 22.61$ and positive disposition towards CT was shown in four subscales: open-mindedness, analyticity, confidence in reasoning, and inquisitiveness. From regression analysis, HKDSE total score (i.e., university entrance examination total score), CT subject grade level, CCTDI truth-seeking, and CCTDI analyticity were identified as the four significant factors associated with their CT cognitive skills. The findings provide significant implications when reviewing the program design and curriculum as well as the addition of CT elements in a separate course to promote students' CT abilities for sustainable development.
\end{abstract}

Keywords: critical thinking; community college; CT cognitive skill; CT disposition; Chinese students

\section{Introduction}

Critical thinking (CT) has been identified as one of the top competencies required by employers, according to the World Economic Forum [1]. It is also an essential skill for community college graduates [2], as this competency is always requested by both articulation partners in tertiary institutions and workplace employers. Students who possess strong $\mathrm{CT}$ can establish commitment and concern, which encourages active engagement; achieve lifelong learning and self-discipline; and modify action in order to achieve sustainable educational development [3]. In addition, CT is an essential human ability to understand the challenges and deal with different risks and changes of the world. It is also one of the key elements of the learning objectives for achieving the sustainable development goals established by United Nations Educational, Scientific and Cultural Organization (UNESCO) $[4,5]$. As a result, CT skills have become an effective change agent to transform policies, practices, and societal norms, and they should be embedded in the learning outcome of higher education [3]. Thus, the educators in community colleges strive hard to foster students' CT abilities for adaptation towards sustainable development. However, research examining community college students' CT abilities is unfortunately scarce, particularly in Asian contexts.

The roots of the CT concept have been traced back to the era of Socrates and Plato [6]. Their students were trained in CT through questioning and probing for deeper, constructed thought that could be applied to new situations [7]. According to Edward Glaser, CT is 
not only a cognitive skill related to logical reasoning, but also extends to incorporate the disposition to consider problems thoughtfully [8]. CT disposition is defined as consistent internal motivation or a person's habitual ways of utilizing CT skills [9]. After years of continuous evolution, a consensus reached by 46 experts was the conceptualization of CT as having two dimensions: cognitive skills and dispositions that a competent critical thinker should possess [9]. Cognitive skills are manifested in six aspects: inference, explanation, evaluation, self-regulation, interpretation, and analysis [10]. Dispositions consists of seven subscales: truth-seeking, open-mindedness, analyticity, systematicity, confidence in reasoning, inquisitiveness, and maturity of judgement [11].

Despite a strong emphasis on improving CT, the CT levels displayed by most community college students are often inadequate. A few small-scale studies in the United States found that community college students had lower CT cognitive skills than those in university $[12,13]$. Only one study reported CT cognitive skills in Asian students in community colleges [14]. This longitudinal study showed a gradual reduction in these students' CT abilities from 2001 to 2010, but at the same time they demonstrated an increased need to improve the CT skills of analyzing, synthesizing, making judgements, and applying theories to ideas, theories, or concepts. This clearly highlights a necessity for teachers to improve the CT of Asian students from community colleges.

CT disposition and CT skill are conceptualized as the two independent dimensions of CT. Their independence means that having a high CT disposition does not necessarily ensure high CT ability, or vice versa. However, some correlation or two-factor analyses have supported a positive relationship between CT disposition and CT ability $[15,16]$. Hence, CT disposition is increasingly recognized as an important factor in CT cognitive skills [17]. More sophisticated studies have employed hierarchical regression analyses to predict CT skill scores for different factors of CT dispositions (or in terms of personality traits) in addition to cognitive abilities. These significant dispositional factors included "need for cognition" [18], "openness to experience" [19], "conscientiousness" [20], "concern for truth" [21], and "analyticity" [22]. CT disposition has usually been discussed in the light of cultural issues. Some studies have indicated that Asian students underperform in CT dispositions when compared with Western students [23-25]. Some scholars posited that the differences in university students' CT level might be related to cultural issues in terms of CT dispositions. According to a literature review on students' CT dispositions in 11 countries, those from Asian countries such as China, Japan, and Hong Kong reflected lower scores than Western students [26].

In addition to this likely impact of cultural issues on CT disposition, an array of socio-demographic and academic factors has been examined that might be associated with CT abilities, even though most of these studies were with undergraduate samples. There is a dearth of studies concerning this topic exclusively in community college students. Gender has been another focus of interest in most of studies, with inconclusive results. Although some studies reported no statistical gender-related differences in CT abilities, others found that male undergraduate students scored higher in all domains $[27,28]$. One study found that female undergraduate students demonstrated a higher level of CT ability only in problem-solving [29]. Studies that investigated age as a factor have shown consistently that senior or older students possessed better CT skills and dispositions, as they had experienced more training in language skills, mathematics thinking, and program-specific knowledge $[27,28,30]$. Furthermore, some studies have revealed that students' training and extracurricular activities were positive factors affecting CT cognitive skills. For example, service learning could develop these skills continuously throughout the students' participation in learning activities [31,32]. This finding implies that constructive engagement between students and educators can enhance the students' learning experiences and CT growth. A more recent example also indicated that undergraduate nursing students in a cooperative learning-based group had higher CT disposition scores than those in an individual practicum (control group) after a four-week clinical practicum [33]. 
The relationship between students' academic achievements and their CT cognitive skills has been reported widely in the literature, with most studies examined in a systematic review showing a positive relationship [34]. Language proficiency is usually considered a CT-contributing factor. Previous studies indicated that students who had achieved higher CT cognitive abilities could demonstrate higher levels of English proficiency or vice versa [35]. However, those who were not educated in their mother tongues tended to focus on translating rather than thinking critically [36]. Manalo and Sheppard further explained that Asian students in English-speaking countries were unable to display the same level of CT evaluation compared with their Western counterparts due to lacking adequate English proficiency [37].

Despite numerous studies having investigated CT cognitive skills in students in higher education, the vast majority focused on undergraduate students, especially in Western populations. Some studies have investigated the factors and teaching strategies that affect the CT abilities of Asian children and university students [38-42]. Little is known about CT cognitive skills in community college students, particularly in Asian contexts. To address this gap, this cross-sectional, correlational study was conducted to assess the levels of CT cognitive skill and CT disposition and identify the associated factors among Chinese community college students. Based on these factors, the current pedagogical methods can be enhanced with the goal of improving students' competence of critical thinking for sustainable development.

Research Question 1: What are the levels of CT cognitive skills among Chinese community college students?

Research Question 2: What are the levels of CT dispositions among Chinese community college students?

Research Question 3: What are the associated factors of CT cognitive skill among Chinese community college students?

\section{Methods}

\subsection{Study Design}

A cross-sectional correlational research design was used to achieve the aim of the study. Prior to implementation, ethical approval (HSEARS20200122001-01) was obtained. Consent from each participant was secured by means of an electronic written consent form.

\subsection{Setting and Participants}

This study was conducted in Hong Kong Community College (HKCC) under the auspices of The Hong Kong Polytechnic University. The HKCC is one of the leading subdegree institutions offering associate's degree and higher diploma programs to graduates completing the Hong Kong Diploma of Secondary Education Examination (HKDSE), the public examination for university entrance. This community college admitted a large proportion of students from the STEM discipline (around 32\%) in the past three years (2017/2018 to 2019/2020) and has achieved an 18-year average articulation rate of $82.9 \%$ going on to degree programs [43]. The target students for this study were recruited from the Division of Science, Engineering and Health Studies (SEHS). The only inclusion criterion was to be a sub-degree student in the second semester of the first year or above in one of the programs under the SEHS division. Those who completed any of the CT tests faster than the specified time (i.e., CCTST in less than $15 \mathrm{~min}$, CCTDI in less than $5 \mathrm{~min}$ ) were excluded. The students were recruited, using convenience sampling, during the period of 26 March 2020 to 27 March 2021. By using a power analysis, a minimum sample size of 178 participants was estimated in order to maintain a medium correlation coefficient of 0.3 , power of 0.8 , and alpha of 0.05 for this study.

\subsection{Instruments}

Three instruments were used to measure the participants' CT cognitive skills, CT dispositions, and socio-demographic and academic factors. 


\subsubsection{CT Cognitive Skills}

The Chinese version of the California Critical Thinking Skills Test (CCTST) was used to measure CT cognitive skills. This instrument is a generic measure of CT that is applicable to students across disciplines in community colleges and universities [44]. The current version of the CCTST consists of 34 multiple-choice questions, which can be classified into the five subscales of inferences, induction, deduction, analysis, and evaluation. The possible score range is from 0 to 34, with a higher score indicating higher CT skills. The average test duration is $45 \mathrm{~min}$ [45]. The English version of the CCTST has demonstrated good validity and reliability in various populations $[45,46]$. For this study, the Cronbach's alpha of the CCTST was 0.811 .

\subsubsection{CT Dispositions}

The Chinese version of the California Critical Thinking Disposition Inventory (CCTDI) was used to measure CT disposition. This 75-item CCTDI assesses a person's willingness to think critically and consists of seven subscales: truth-seeking, open-mindedness, analyticity, systematicity, CT confidence, inquisitiveness, and maturity of judgement $[47,48]$. The instrument is rated on a 6-point Likert scale, $(1=$ strongly agree and $6=$ strongly disagree) As the number of items in each subscale is different, the subscale score is converted into a range of 10 to 60 . The total CCTDI score is the sum of the subscale scores, ranging from 70 to 420 , and the time for completion is 30 minutes. The CCTDI has been reported as having a Cronbach's alpha of 0.90 for the total scale and Cronbach's alphas of 0.72 to 0.80 for the subscales [11]. For this study, the Cronbach's alpha was 0.738 .

\subsubsection{Socio-Demographic and Academic Characteristics}

A self-developed questionnaire was used to collect data about socio-demographics and academic profiles (including age, gender, year of study, and type of sub-degree program), prior education background, current academic achievements (including CT subject grade level, cumulative GPA, HKDSE Chinese score, HKDSE English score, HKDSE total score), and previous training and experience. This online questionnaire is written in Chinese and the average completion time for this study was 10 minutes. The questionnaire items were reviewed by a panel of five experts and the content validity index was 0.927 .

\subsection{Procedure}

During the second semester of the 2019/2020 academic year, students from the Division of SEHS in HKCC was recruited via internal college emails. Those who met the inclusion criteria were invited to join an online meeting using Microsoft Teams, in groups that were arranged according to their convenience. At the beginning of the online meetings, the purpose of the study and the utilization of the gathered information were explained. The participants were reassured that their individual performances on the CT tests would not be disclosed and that there would not be any impact on their college course grades or studies. After submitting their signed electronic consent forms by email, the participants were given instructions for completing the online questionnaire through a website designated for the purpose (www.insightassessment.com). They were also asked to complete an online questionnaire on their socio-demographic and academic characteristics. To ensure anonymity during the data collection, each student was assigned to a PIN number that was used to submit all of the online questionnaires. Thus, their personal information, such as names and student numbers, were not linked directly with their CT scores or the content of the questionnaires in any single record.

\subsection{Data Analysis}

The overall CCTST and CCTDI scores and the corresponding subscale scores were evaluated by the Insight Assessment Company. The author retrieved and downloaded these data from the company's online system. Their CCTST and CCTDI scores and the 
data obtained from the online questionnaire were imported into Statistical Package for the Social Sciences (SPSS) version 26 for statistical analysis.

A normality test was performed prior to data analysis to determine whether parametric or non-parametric statistical tests would be applied. The Kolmogorov-Smirnova test and Shapiro-Wilk test were used to evaluate normal data distribution for participants' CCTST and CCTDI scores. The data were considered normally distributed since the significance value of the Kolmogorov-Smirnova test or Shapiro-Wilk test was larger than 0.05 and the values of skewness and kurtosis were between \pm 3.00 and \pm 7.00 , respectively [49]. Thus, parametric statistical tests were used in this study.

The participants' socio-demographic and academic profiles, as well as their overall and subscale CCTST and CCTDI scores, were analyzed using descriptive statistics in terms of numbers, percentages, ranges, means, and standard deviations. To investigate the associated factors of CT cognitive skills, univariate and multivariate analyses were performed. Univariate analyses were conducted to determine the associations between overall CCTST scores with selected socio-demographic and academic characteristics, previous training and experience, and CT dispositions. Overall CCTST scores were used to assess CT cognitive skills, which were treated as continuous dependent variables. The independent variables, with continuous/interval scale data, included socio-demographic characteristics such as age, year of study, and academic performance measured by CT subject grade level ( 0 for not taking any CT subject yet and grade levels 1 to 10), cumulative GPA, HKDSE Chinese score (1 to 7), HKDSE English score (1 to 7), HKDSE total score (the five best subjects), and CCTDI subscale scores. In addition, all categorical independent variables, namely, gender ( 0 for male and 1 for female), sub-degree program ( 1 for higher diploma and 2 for associate's degree), types of secondary school (1 for Chinese secondary school, 2 for AngioChinese school, 3 for international school/direct subsidy scheme schools, and 4 for overseas high school), main medium of instruction in secondary school (1 for English and 2 for Cantonese), joined HKDSE or not (0 for SAT and TOEFL and 1 for HKDSE examination), whether having studied in a post-secondary institution before joining community college ( 0 for no and 1 for yes), and their previous training and experiences (i.e., work-integrated education (e.g., internship or practicum) ( 0 for no and 1 for yes), co-curricular activities ( 0 for no and 1 for yes), extracurricular activities ( 0 for no and 1 for yes), work experience ( 0 for no and 1 for yes), and voluntary activities ( 0 for no and 1 for yes)), were included in the analysis. Student's t-tests or Pearson's correlation tests were utilized when appropriate. Variables with $p$-values less than 0.25 in univariate analyses were considered as potential variables for stepwise multivariate regression analyses. The variance inflation factor (VIF) for the variables was less than 5, indicating that no multicollinearity occurred among those independent variables [50]. All statistical tests were two-sided and statistical significance was defined as a $p$-value of less than 0.05 . The adjusted $R^{2}$ values and regression coefficients were also examined. From the results of multivariate regression analyses, the most significant variables (i.e., the associated factors) contributing to students' CT cognitive skills could be determined.

\section{Results}

\subsection{Demographics and Academic Characteristics}

In total, 213 students were invited for this study. Four of them were excluded. Two finished the CCTST test in less than $15 \mathrm{~min}$ and one finished the CCTDI test in less than 5 min, which may have indicated false test results [45,48]. In addition, one student refused to participate in the online questionnaire on socio-demographic and academic characteristics after completing both the CCTST and CCTDI tests. Finally, only 209 students were included in the statistical analyses, a response rate of $98.1 \%$.

The participants' socio-demographic characteristics are presented in Table 1. Their mean age \pm standard deviation (S.D.) was $19.58 \pm 1.24$ years; most participants were male $(60.3 \%)$ and Year 2 students (58.9\%). Most (78.9\%) were studying in associate's degree programs in the community college. During their secondary school study, $52.6 \%$ 
had studied in Angio-Chinese schools, whereas $45.0 \%$ had studied in Chinese secondary schools. Their mediums of instruction used in secondary school were English (54.5\%) and Cantonese (45.5\%). As measures of academic achievement, the average cumulative GPA was $3.32 \pm 0.36$ (out of 4.30 ). The CT subject grade level of 138 students $(66 \%$ ) who studied this subject was 4.96. A total of 208 out of 209 students (99.5\%) took the HKDSE examination. The mean scores for HKDSE Chinese, HKDSE English, and HKDSE total for the 208 students were $2.85,2.89$, and 16.77 , respectively.

Table 1. Socio-demographic and academic characteristics of all participants $(n=209)$.

\begin{tabular}{|c|c|c|}
\hline $\begin{array}{c}\text { Socio-Demographic and Academic } \\
\text { Characteristics }\end{array}$ & Number (n)/Percentage (\%) & Mean (S.D.) \\
\hline Age & $209(100)$ & $19.58(1.24)$ \\
\hline \multicolumn{3}{|l|}{ Gender } \\
\hline Male & $126(60.3)$ & \\
\hline Female & $83(39.7)$ & \\
\hline \multicolumn{3}{|l|}{ Year of study } \\
\hline Year 1 & $66(31.6)$ & \\
\hline Year 2 & $123(58.9)$ & \\
\hline Year 3 or above & $20(9.6)$ & \\
\hline \multicolumn{3}{|l|}{ Type of sub-degree program } \\
\hline Associate's degree & $165(78.9)$ & \\
\hline Higher diploma & $44(21.1)$ & \\
\hline \multicolumn{3}{|l|}{ Type of secondary school } \\
\hline Chinese secondary school & $94(45.0)$ & \\
\hline Angio-Chinese school & $110(52.6)$ & \\
\hline $\begin{array}{l}\text { International school/Direct subsidy } \\
\text { scheme school }\end{array}$ & $4(1.9)$ & \\
\hline Overseas high school & $1(0.5)$ & \\
\hline \multicolumn{3}{|l|}{$\begin{array}{c}\text { Medium of instruction in secondary } \\
\text { school }\end{array}$} \\
\hline English & $114(54.5)$ & \\
\hline Cantonese & $95(45.5)$ & \\
\hline \multicolumn{3}{|l|}{ Public examination taken } \\
\hline HKDSE & $208(99.5)$ & \\
\hline SAT and TOEFL & $1(0.5)$ & \\
\hline \multicolumn{3}{|l|}{$\begin{array}{l}\text { Studied in post-secondary institutions } \\
\text { before admission to community college }\end{array}$} \\
\hline Yes & $10(4.8)$ & \\
\hline No & $199(95.2)$ & \\
\hline \multicolumn{3}{|l|}{ Academic achievements } \\
\hline Cumulative grade point average & $209(100)$ & $3.32(0.36)$ \\
\hline CT subject grade level & $138(66.0)$ & $4.96(3.83)$ \\
\hline HKDSE Chinese score & $208(99.5)$ & $2.85(0.76)$ \\
\hline HKDSE English score & $208(99.5)$ & $2.89(0.73)$ \\
\hline HKDSE total score & $208(99.5)$ & $16.77(2.42)$ \\
\hline
\end{tabular}

\subsection{Students' Overall and Subscale Scores of CCTST and CCTDI}

Descriptive statistics for the CCTST and CCTDI overall and subscale measurements are presented in Table 2. The mean overall CCTST score for all students $(\mathrm{N}=209)$ was $17.82 \pm 4.10$, indicating that their average CT cognitive skills attained the upper score limit of the moderate level. By subscales, induction, deduction, inference, analysis, and evaluation were also rated as moderate [45]. For overall CCTDI, the mean score was $278.81 \pm 22.61(\mathrm{~N}=209)$, which indicated a rating of inconsistent/ambivalent disposition, approaching positive disposition. For the CCTDI subscales, open-mindedness, analyticity, confidence in reasoning, and inquisitiveness were above 40 , indicating a positive CT disposition, whereas truth-seeking, systematicity, and maturity of judgment were below 40, indicating inconsistent/ambivalent disposition towards CT [48]. 
Table 2. Mean overall and subscale scores of CCTST and CCTDI for all participants $(n=209)$.

\begin{tabular}{ccc}
\hline CCTST & Mean (S.D.) & Range \\
\hline Overall & $17.82(4.10)$ & $7-28$ \\
\hline Induction subscale & $9.57(2.27)$ & $4-14$ \\
\hline Deduction subscale & $8.25(2.65)$ & $3-15$ \\
\hline Inference subscale & $8.68(2.57)$ & $3-14$ \\
\hline Analysis subscale & $4.27(1.34)$ & $0-7$ \\
\hline Evaluation subscale & $4.87(1.70)$ & $1-9$ \\
\hline CCTDI & & $196-341$ \\
\hline Overall & $278.81(22.61)$ & $15-43$ \\
\hline Truth-seeking & $30.81(4.81)$ & $29-52$ \\
\hline Open-mindedness & $40.11(3.67)$ & $27-53$ \\
\hline Analyticity & $41.90(4.70)$ & $22-52$ \\
\hline Systematicity & $37.38(5.53)$ & $19-58$ \\
\hline Confidence in reasoning & $42.11(5.64)$ & $25-60$ \\
\hline Inquisitiveness & $48.05(5.61)$ & $22-58$ \\
\hline Maturity of judgment & $38.71(5.83)$ &
\end{tabular}

\subsection{Factors Associated with CT Skills}

Univariate and multivariate analysis results are shown in Table 3. In multivariate analysis, variables with a $p$-value less than 0.25 from univariate analyses were tested as predictors of CT cognitive skills, including type of sub-degree program, previous experience with extracurricular activities, CT subject grade level, cumulative GPA, HKDSE Chinese score, HKDSE total score, and seven CCTDI subscales: truth-seeking, open-mindedness, analyticity, systematicity, confidence in reasoning, inquisitiveness and maturity of judgment.

Table 3. Association between students' socio-demographic and academic variables, CCTDI subscales with overall CCTST scores in the univariate and multivariate analyses $(n=209)$.

\begin{tabular}{|c|c|c|c|c|}
\hline \multirow[b]{3}{*}{ Socio-demographic Variables } & \multicolumn{4}{|c|}{ CCTST (Overall) } \\
\hline & \multicolumn{2}{|c|}{$\begin{array}{c}\text { Univariate Analysis of } \\
\text { Variance (F) } \\
\text { and Correlation }(r)\end{array}$} & \multicolumn{2}{|c|}{ Multivariate Analysis } \\
\hline & $\mathrm{F} / r^{\#}$ & $p$ & $\beta(\mathrm{SE})$ & $p$ \\
\hline Age & $-0.01^{\#}$ & NS & $\mathrm{NE}$ & $\mathrm{NE}$ \\
\hline Gender (male) & 0.67 & NS & $\mathrm{NE}$ & NE \\
\hline Year of study & $0.02^{\#}$ & NS & $\mathrm{NE}$ & $\mathrm{NE}$ \\
\hline $\begin{array}{l}\text { Type of sub-degree program } \\
\text { (associate's degree) }\end{array}$ & 1.60 & 0.037 & NS & NS \\
\hline $\begin{array}{l}\text { Type of secondary school (Chinese } \\
\text { secondary school) }\end{array}$ & 0.78 & NS & NE & $\mathrm{NE}$ \\
\hline $\begin{array}{l}\text { Medium of instruction in secondary } \\
\text { school (English) }\end{array}$ & 0.02 & NS & $\mathrm{NE}$ & $\mathrm{NE}$ \\
\hline Public examination taken (HKDSE) & - & - & NE & NE \\
\hline $\begin{array}{l}\text { Studied in post-secondary institutions } \\
\text { before admission to community college }\end{array}$ & 0.08 & NS & NE & $\mathrm{NE}$ \\
\hline \multicolumn{5}{|l|}{ Previous Training and Experience } \\
\hline $\begin{array}{l}\text { Work-integrated education (e.g., } \\
\text { internship or practicum) }\end{array}$ & 1.12 & NS & NE & NE \\
\hline
\end{tabular}


Table 3. Cont.

\begin{tabular}{|c|c|c|c|c|}
\hline & \multicolumn{4}{|c|}{ CCTST (Overall) } \\
\hline & \multicolumn{2}{|c|}{$\begin{array}{c}\text { Univariate Analysis of } \\
\text { Variance (F) } \\
\text { and Correlation }(r)\end{array}$} & \multicolumn{2}{|c|}{ Multivariate Analysis } \\
\hline Co-curricular activities & 0.02 & NS & NE & NE \\
\hline Extracurricular activities & 6.17 & 0.014 & NS & NS \\
\hline Work experience & 0.14 & NS & NE & NE \\
\hline Voluntary activities & 0.02 & NS & $\mathrm{NE}$ & $\mathrm{NE}$ \\
\hline \multicolumn{5}{|l|}{ Academic Performance } \\
\hline CT subject grade level & $0.226^{\#}$ & 0.001 & 0.188 & 0.004 \\
\hline Cumulative grade point average & $0.166^{\#}$ & 0.016 & NS & NS \\
\hline HKDSE Chinese score & $0.136^{\#}$ & 0.049 & NS & NS \\
\hline HKDSE English score & $0.034^{\#}$ & NS & NE & NE \\
\hline HKDSE total score & $0.260^{\#}$ & $<0.001$ & 0.192 & 0.004 \\
\hline \multicolumn{5}{|l|}{ CCTDI Subscales } \\
\hline Truth-seeking & $0.251^{\#}$ & $<0.001$ & 0.183 & 0.006 \\
\hline Open-mindedness & $0.109^{\#}$ & 0.115 & NS & NS \\
\hline Analyticity & $0.208^{\#}$ & 0.003 & 0.143 & 0.030 \\
\hline Systematicity & $0.108^{\#}$ & 0.119 & NS & NS \\
\hline Confidence in reasoning & $0.095^{\#}$ & 0.171 & NS & NS \\
\hline Inquisitiveness & $0.200^{\#}$ & 0.004 & NS & NS \\
\hline Maturity of judgment & $0.249^{\#}$ & $<0.001$ & NS & NS \\
\hline $\mathrm{R}^{2}$ & & & 0.170 & \\
\hline Adjusted $\mathrm{R}^{2}$ & & & 0.153 & \\
\hline
\end{tabular}

\#: represent using correlation test; $p$ : probability value; $\beta$ : regression coefficient; SE: standard error of the regression coefficient; NE: not entered into the multivariate regression model, NS: not significant in the analysis.

According to multivariate analyses, HKDSE total score $(\beta=0.192, p=0.004)$ and CT subject grade level $(\beta=0.188, p=0.004)$ were significantly associated with higher overall CCTST scores. Truth-seeking $(\beta=0.183, p=0.006)$ and analyticity $(\beta=0.143, p=0.030)$ were two other CCTDI subscales that exhibited a significant association with higher overall CCTST scores (adjusted $R^{2}=0.153$ ). To further elaborate, HKDSE total score, CT subject grade level, and CCTDI subscales truth-seeking and analyticity were significant associated factors $(p<0.05)$ of overall CCTST. The findings showed that $15.3 \%$ of the variance in CT cognitive skills could be explained from the above factors.

\section{Discussion}

To our best knowledge, this is the first study of its kind to assess the CT abilities of community college students in an Asian context. Further discussion of the results responding to the three research questions and their sustainability implications are presented below.

\subsection{Research Question 1: CT Cognitive Skills in Chinese Community College Students}

The Chinese community college students' average score for overall CT cognitive skills $(17.82 \pm 4.10)$ was within the upper score limit for the moderate level and close to the lower score limit for the strong level. It might be difficult to determine whether Chinese community college students have better or poorer CT cognitive skills than their counterparts in other countries because of the different scales used. For instance, in two large-scale studies related to CT in U.S. and U.S. and Canadian community college students, the Educational Testing Service ${ }^{\circledR}$ Proficiency Profile and HEIghten CT assessment tools were used $[14,51]$. Furthermore, the subscale scores for those studies may not have been specified and discussed clearly enough for comparison with our study. Nevertheless, we found that the Chinese community college students' overall CCTST scores (17.82 \pm 4.10$)$ were comparable with Chinese students from a baccalaureate nursing program in Hong 
Kong (17.52 \pm 3.52$)$ [52]. In addition, when compared with associate's degree graduates from 23 community colleges in Virginia, U.S., all of the CCTST subscale scores from the current study were slightly higher than the reports by Fields with a similar sample size (188 associate's degree graduates) and using the same CT instrument [53]. The comparisons of CCTST subscale scores between Fields' study and the current study are given in Table 4. It is important to identify the associate factors of CT cognitive skills (our research question 3 ) to determine how to sustain these skills.

Table 4. Comparisons of CCTST subscale scores between Field's study [53] and the current study.

\begin{tabular}{cccc}
\hline CCTST Scores & $\begin{array}{c}\text { 209 Chinese Students } \\
\text { from Hong Kong } \\
\text { Community College in } \\
\text { 2021 (mean } \pm \text { S.D.) }\end{array}$ & $\begin{array}{c}\text { Associate's Degree } \\
\text { Graduates from } \\
\text { 23 Virginia } \\
\text { Community Colleges } \\
\text { in 2017 } \\
\text { (mean } \pm \text { S.D.) }\end{array}$ & $\begin{array}{c}\text { Range of } \\
\text { Moderate Level }\end{array}$ \\
\hline Induction subscale & $9.57 \pm 2.27$ & $9.06 \pm 2.64$ & $6-11$ \\
\hline Deduction subscale & $8.25 \pm 2.65$ & $6.45 \pm 2.75$ & $6-11$ \\
\hline Inference subscale & $8.68 \pm 2.57$ & $6.96 \pm 2.61$ & $6-11$ \\
\hline Analysis subscale & $4.27 \pm 1.34$ & $4.23 \pm 1.51$ & $3-4$ \\
\hline Evaluation subscale & $4.87 \pm 1.70$ & $4.38 \pm 2.00$ & $4-7$ \\
\hline
\end{tabular}

\subsection{Research Question 2: CT Dispositions in Chinese Community College Students}

For CT dispositions, the Chinese community college students' overall CCTDI scores were $278.81 \pm 22.61$, which is regarded as an "inconsistent/ambivalent" disposition towards CT. As stated in the Insight Assessment [48], the students with scores indicating this level of CCTDI can be described as those who may reject the challenge or find this path too frightening, and hence they would be more likely to use non-reflective approaches to dealing with life and work issues instead. For comparison, the overall CCTDI score (278.81 \pm 22.61$)$ was found to be higher than that from a study by Chang et al. [52] with 101 Chinese nursing degree students $(269.50 \pm 19.23)$, but slightly lower than the mean of $284.85 \pm 29.60$ for 224 community college students in the U.S. [30], as shown in Table 5 . In addition, the Chinese community college students demonstrated a positive disposition towards $\mathrm{CT}$ in four subscales, namely, open-mindedness, analyticity, confidence in reasoning, and inquisitiveness, whereas Chang et al. [52] found that only two CCTDI subscales, inquisitiveness and analyticity, fell into the positive CT disposition category. In contrast, a sample of American community college students demonstrated positive CT dispositions in five subscales and the overall score. Students who score in this range are more likely to display this mentality attribute consistently. From these CCTDI subscale scores, the strongest and lowest scores were obtained in inquisitiveness (48.05 \pm 5.61$)$ and truthseeking (30.81 \pm 4.81$)$, respectively. The above results were found to be consistent with the reports by Wangensteen et al. [54] for Norwegian nursing students, and Chang et al. [52] for Chinese nursing students, in which the same subscale scores were ranked highest and lowest. Similar results have been noted from other studies in which the lowest subscale scores were for truth seeking [55-57]. Furthermore, Yeh and Chen compared the CT dispositions of Chinese and American graduate nursing students and concluded that the American students had significantly higher scores than the Chinese students on the CCTDI subscales of truth-seeking, open-mindedness, and maturity of judgement [58]. They considered that the cultural differences may contribute to the group differences in these subscales of CT disposition. Our study results might imply that our Chinese community college students have similar or better $\mathrm{CT}$ dispositions than their counterparts studying nursing degrees. However, the majority of previous studies focused on nursing degree students and not community college students. In order to improve CT disposition with the aim of sustaining 
CT skills for better articulation with further studies or employment, more research should be conducted with Chinese community college students from different disciplines on CT disposition and its associated factors contributing to development on each CCTDI subscale.

Table 5. Comparisons of CCTDI overall and subscale scores of students from different studies [30,52].

\begin{tabular}{|c|c|c|c|c|}
\hline $\begin{array}{l}\text { CCTDI Scores } \\
\text { (mean } \pm \text { S.D.) }\end{array}$ & $\begin{array}{l}209 \text { Chinese Students } \\
\text { from Hong Kong } \\
\text { Community College } \\
\text { in } 2021\end{array}$ & $\begin{array}{l}224 \text { Students from a } \\
\text { Community College } \\
\text { in the U.S. in } 1996\end{array}$ & $\begin{array}{l}101 \text { Chinese Nursing } \\
\text { Degree Students in } \\
\text { Hong Kong in } 2001\end{array}$ & $\begin{array}{c}\text { Range of Inconsistent } \\
\text { or Ambivalent/Positive } \\
\text { Disposition }\end{array}$ \\
\hline Truth-seeking & $30.81 \pm 4.81$ & $32.45 \pm 6.75$ & $31.82 \pm 4.22$ & $30-39 / 40-49$ \\
\hline Open-mindedness & $40.11 \pm 3.67$ & $41.05 \pm 5.86$ & $38.38 \pm 3.86$ & $30-39 / 40-49$ \\
\hline Analyticity & $41.90 \pm 4.70$ & $43.25 \pm 5.15$ & $41.47 \pm 3.88$ & $30-39 / 40-49$ \\
\hline Systematicity & $37.38 \pm 5.53$ & $38.29 \pm 7.20$ & $37.47 \pm 4.69$ & $30-39 / 40-49$ \\
\hline $\begin{array}{l}\text { Confidence in } \\
\text { reasoning }\end{array}$ & $42.11 \pm 5.64$ & $43.37 \pm 6.59$ & $39.51 \pm 5.09$ & $30-39 / 40-49$ \\
\hline Inquisitiveness & $48.05 \pm 5.61$ & $45.64 \pm 6.79$ & $43.37 \pm 5.18$ & $30-39 / 40-49$ \\
\hline $\begin{array}{c}\text { Maturity of } \\
\text { judgment }\end{array}$ & $38.71 \pm 5.83$ & $40.79 \pm 7.16$ & $37.05 \pm 4.92$ & $30-39 / 40-49$ \\
\hline CCTDI (overall) & $278.81 \pm 22.61$ & $284.85 \pm 29.60$ & $269.50 \pm 19.23$ & $210-279 / 280-349$ \\
\hline
\end{tabular}

\subsection{Research Question 3: Associated Factors of CT Cognitive Skills among Chinese Community College Students}

In our study, four significant associated factors of CT cognitive ability found from the overall CCTST score were HKDSE total score, CT subject grade level, CCTDI truthseeking score, and CCTDI analyticity score. This implies that at least one factor linked to overall academic performance, one specifically related to achievement in CT learning, and one related to CT dispositions should be included in the student factors contributing to CT cognitive skills. Although each of these factors had been identified individually as significant factor in previous literature [59-61], such a complete set of factors associated with CT skills can be regarded as new findings from this study.

Previous studies have addressed the relationship between academic performance and CT ability. The HKDSE is a Hong Kong university entrance examination, with the HKDSE total score serving as a standard indicator of college students' academic performance. Its nature is similar to other foreign university entrance examinations, like the Scholastic Assessment Test (SAT) verbal score and SAT math score in Western countries. A previous study conducted by Facione [60] in the U.S. demonstrated that SAT verbal score $(r=0.55$, $p<0.001)$ and SAT math score $(r=0.44, p<0.001)$ were significantly correlated to the CCTST, and the stepwise multiple regression model showed that the CCTST score could be significantly predicted by SAT verbal score, SAT math score, and GPA. Stone et al. [61] assessed the CT ability of students in nursing programs, including associate's degrees, undergraduate degrees, master's degrees, and doctoral degrees. Their study revealed that the CCTST score was significantly correlated with SAT verbal and math scores in the moderate level ( $r=0.39$ and 0.47, respectively). Bycio and Allen (2009) [59] also performed stepwise regression using SAT verbal score, SAT math score, MFAT-Business, GPA, and AACSB-Importance to predict the CCTST scores of business students. They found that the only significant predictors were the two SAT scores (Model $\mathrm{R}=0.56, p<0.001$ ). The findings in this study demonstrate that the HKDSE, being a university-entrance score, was the most significant factor for the CCTST score, and this is in line with previous studies.

Our study included CT subject grade level in the stepwise multiple regression model and found it to be the second most significant factor for the CCTST score. This implies that the addition of CT courses to program curricula is essential to promote students CT abilities. CT can be taught by both explicit or implicit activities in the curriculum. Explicit activities mean that the lessons are designed directly to teach specific CT skills, whereas implicit activities mean that the CT content is infused into some exercises and not particularly labelled as "critical thinking" [62]. Many studies have investigated the 
effectiveness of explicit or implicit CT activities in the enhancement of students' $\mathrm{CT}$ abilities. However, most of these only compared pre- and post- or control and experiment groups CT scores or GPAs to study the differences in their CT abilities. As indicated by the current findings, the outcome of explicit activity in the form of a CT course grade is also one of the most important indicators of CT ability.

Concerning the effect of CT disposition on CT ability, the overall CCTDI score was determined to be significantly correlated with the overall CCTST score obtained from the Chinese community college students $(r=0.283, p<0.001)$. This correlation was stronger than those in other relevant studies. For example, Ricketts [63] adopted the total critical thinking disposition (EMI) score and the Youth Leadership Decision-Making Test score to measure, respectively, the CT disposition and CT skills of youth leaders in the National FFA Organization. He found that EMI score was significantly correlated with the total CT skill score $(r=0.18, p<0.05)$. Miller [64] investigated the relationship between CCTDI and CCTST scores of doctoral pharmacy students. The admission and final CCTDI scores ( $r=0.20$ and $r=0.22$ ) were significantly correlated with the respective changes of CCTST scores at admission and final CCTST. Profetto-McGrath [65] also examined the relationship between CCTDI and CCTST scores of nursing students using a chi-squared test. Their result showed a significant relationship between CCTST and CCTDI scores $\left(\chi^{2}=9.37, p=0.14\right.$, power $>0.80$ ). All of these consistent positive relationships indicate that CT cognitive skills and dispositions are inter-related. Students with higher CT cognitive skills tend to possess higher $\mathrm{CT}$ dispositions, whereas those with lower $\mathrm{CT}$ cognitive skills will have lower CT dispositions.

Of the various studies using CT disposition score as an independent variable to account for CT ability, only Ku and Ho (2010) [21] and Ghadi et al. (2015) [22] studied Asian undergraduate students. The current study had a different target group, again, focusing on Chinese community college students. Apart from the factors of HKDSE total score $(\beta=0.192, p=0.004)$ and CT subject grade level $(\beta=0.188, p=0.004)$, truth-seeking ( $\beta=0.183, p=0.006)$ and analyticity $(\beta=0.143, p=0.03)$ were the two CCTDI subscales significantly associated with overall CCTST score $\left(R^{2}=0.17\right)$. The first Asian study applied the Verbal Comprehension Index (VCI) and the Halpern Critical Thinking Assessment (HCTA) to measure the CT ability of Chinese undergraduate students and found that VCI $(\beta=0.40, p<0.01)$ and concern for truth $(\beta=0.28, p<0.01)$ significantly contributed to CT ability $\left(R^{2}=0.32\right)$. The latter study administrated the CCTST to evaluate the CT ability of Malaysian undergraduate students and showed that the scores for analyticity $(\beta=0.111$, $p<0.001)$, truth-seeking $(\beta=-0.116, p<0.001)$, self-confidence $(\beta=-0.083, p<0.001)$, and maturity of judgment $(\beta=-0.078, p<0.001)$ were the significant factors for CT ability $\left(R^{2}=0.15\right)$. Although the students' education levels and nationalities were different in these studies, the present findings still demonstrate that truth-seeking and analyticity scores were the significant factors in the CCTDI subscales for CT ability, with the regression coefficients ( $\beta$ ) all positive. In other words, "seeking for the truth to get the right answer" as well as "anticipating consequences by applying deep reasoning" can influence the CT cognitive skills of Chinese community college students. Since articulation to senior-year university programs is the main personal goal of community college students, they certainly consider course grade point as the most important learning outcome, above other essential skills such as CT abilities and interpersonal skills. Some of them even sacrifice social or extracurricular activities and allocate more time to their studies in order to earn higher scores. Thus, any activity or task that is not counted towards their grades may not arouse their interest or participation. This phenomenon could explain why CT disposition in truth-seeking was not significant to CT skills in the studies of Western university and community college students. Therefore, the design of continuous assessment tasks requiring the application of CT skills rather than merely the memorization of knowledge should be encouraged. On the whole, it is highly advocated to review the program curriculum, course content, and methods of teaching and learning effectively to meet the learning outcomes through re-organizing and rethinking in higher education institutions for sustainability [3]. Once 
students have mastered the thinking skills and achieved the required learning outcomes, their CT dispositions and hence CT cognitive skills can be improved further as a result of this motivation.

\section{Conclusions}

Faced with a fast-paced, ever-changing environment, educators must equip community college students with CT competence for critical analysis and lifelong learning to achieve sustainable development. This study was conducted in a community college in Hong Kong. It investigated students' CT cognitive skills and dispositions using online CCTST and CCTDI instruments. Their overall CT cognitive skills were found to be comparable with those of Western community college students (i.e., moderate level), whereas their overall CCTDI score indicated an inconsistent/ambivalent CT disposition and only some subscales were in the positive category. From the regression analysis, our study identified that community college students' CT skills are not only associated with their academic performances (HKDSE total score), but also with the amount of CT knowledge and thinking skills being learned explicitly from a CT subject (CT subject grade level) and their CT dispositions (truth-seeking and analyticity). These findings are valuable and beneficial to community college educators because they address the need to add CT courses to program curricula, since this explicit teaching activity can promote CT abilities. Future research is recommended to conduct focus group interviews with (1) students about the factors influencing their CT cognitive skills, and (2) teaching staff about the pedagogical strategies for improving their students' CT skills. This also aids in the validation of quantitative findings with qualitative data for a better understanding of the issue.

Author Contributions: Conceptualization, S.-Y.N., K.C. and H.-L.C.; methodology, S.-Y.N., K.C. and H.-L.C.; software, S.-Y.N.; formal analysis, S.-Y.N., K.C. and H.-L.C.; writing-original draft preparation, S.-Y.N., K.C. and H.-L.C.; writing-review and editing, S.-Y.N., K.C. and H.-L.C.; supervision, K.C. and H.-L.C. All authors have read and agreed to the published version of the manuscript.

Funding: This research was partially funded by the University Grant Committee (UGC) Funding Scheme for Teaching and Learning Related Proposals (2016-19 Triennium), grant number PolyU6/T\&L/16-19.

Institutional Review Board Statement: The study was conducted in accordance with the Declaration of Helsinki and approved by the Institutional Review Board of PolyU Institutional Review Board of The Hong Kong Polytechnic University (protocol code HSEARS20200122001-01 and date of approval to start on 1 February 2020).

Informed Consent Statement: Written informed consent was obtained from all subjects involved in the study.

Data Availability Statement: Fundamental data are contained in the article. For additional details, please contact the first author.

Conflicts of Interest: The authors declare no conflict of interest.

\section{References}

1. World Economic Forum. The Future of Jobs Report 2020, Geneva, Switzerland. Available online: https:/ /www.weforum.org/ reports/the-future-of-jobs-report-2020 (accessed on 22 December 2021).

2. Flores, K.L.; Matkin, G.S.; Burbach, M.E.; Quinn, C.E.; Harding, H. Deficient Critical Thinking Skills among College Graduates: Implications for Leadership. Educ. Philos. Theory 2012, 44, 212-230. [CrossRef]

3. Svanstrom, M.; Lozano-Garcia, F.J.; Rowe, D. Learning Outcomes for Sustainable Development in Higher Education. Int. J. Sustain. High. Educ. 2008, 9, 339-351. [CrossRef]

4. Rieckmann, M.; Mindt, L.; Gardiner, S. Division for Inclusion, Peace and Sustainable Development, Education Sector. In Education for Sustainable Development Goals: Learning Objectives; UNESCO: Paris, France, 2017.

5. UNESCO. UNESCO Intersectoral Strategy on Philosophy. Diogenes 2009, 56, 95-100. [CrossRef]

6. Paul, R.W.; Elder, L.; Bartell, T. California Teacher Preparation for Instruction in Critical Thinking: Research Findings and Policy Recommendations; California Commission on Teacher Credentialing: New York, NY, USA, 1997; pp. 1-194. 
7. Fahim, M.; Bagheri, M. Fostering Critical Thinking through Socrates' Questioning in Iranian Language Institute. J. Lang. Teach. Res. 2012, 3, 1122-1127. [CrossRef]

8. Glaser, E. An Experiment in the Development of Critical Thinking. In Advanced School of Education at Teacher's College; Columbia University: New York, NY, USA, 1941; p. 5.

9. Facione, P.A. Critical Thinking: A Statement of Expert Consensus for Purposes of Educational Assessment and Instruction. In Research Findings and Recommendations; American Philosophical Association: Newark, DE, USA, 1990. Available online: https: / / eric.ed.gov / ?id=ED315423 (accessed on 22 December 2021).

10. Facione, P.A. Critical thinking: What it is and why it counts. Insight Assess. 2011, 2007, 1-23.

11. Facione, N.C.; Facione, P.A.; Sánchez, C.A. Critical Thinking Disposition as a Measure of Competent Clinical Judgement: The Development of the California Critical Thinking Disposition Inventory. J. Nurs. Educ. 1994, 33, 345-350. [CrossRef]

12. Butler, H.A. Halpern Critical Thinking Assessment Predicts Real-World Outcomes of Critical Thinking. Appl. Cogn. Psychol. 2012, 26, 721-729. [CrossRef]

13. Poe, A.B. Assessing Critical Thinking Skills through Collegiate Livestock Evaluation Participation. Ph.D. Thesis, Texas A\&M University, College Station, TX, USA, August 2016.

14. Liu, O.L.; Roohr, K.C. Investigating 10-Year Trends of Learning Outcomes at Community Colleges. ETS Res. Rep. Ser. 2013, 2013, $1-45$.

15. Taube, K.T. Critical Thinking Ability and Disposition as Factors of Performance on a Written Critical Thinking Test. J. Gen. Educ. 1997, 46, 129-164.

16. Yang, Y.T.C.; Chou, H.A. Beyond Critical Thinking Skills: Investigating the Relationship between Critical Thinking Skills and Dispositions through Different Online Instructional Strategies. Br. J. Educ. Technol. 2008, 39, 666-684. [CrossRef]

17. Facione, P.A. The Disposition toward Critical Thinking: Its Character, Measurement, and Relationship to Critical Thinking Skill. Informal Log. 2000, 20, 61-84. [CrossRef]

18. West, R.F.; Toplak, M.E.; Stanovich, K.E. Heuristics and Biases as Measures of Critical Thinking: Associations with Cognitive Ability and Thinking Dispositions. J. Educ. Psychol. 2008, 100, 930-941. [CrossRef]

19. Clifford, J.S.; Boufal, M.M.; Kurtz, J.E. Personality Traits and Critical Thinking Skills in College Students: Empirical Tests of a Two-factor Theory. Assessment 2004, 11, 169-176. [CrossRef]

20. Spector, P.E.; Schneider, J.R.; Vance, C.A.; Hezlett, S.A. The Relation of Cognitive Ability and Personality Traits to Assessment Center Performance. J. Appl. Soc. Psychol. 2000, 30, 1474-1491. [CrossRef]

21. Ku, K.Y.; Ho, I.T. Dispositional Factors Predicting Chinese Students' Critical Thinking Performance. Personal. Individ. Differ. 2010, 48, 54-58. [CrossRef]

22. Ghadi, I.N.; Bakar, K.A.; Njie, B. Influences of Critical Thinking Dispositions on Critical Thinking Skills of Undergraduate Students at a Malaysian Public University. J. Educ. Res. Rev. 2015, 3, $23-31$.

23. Lun, V.M.C.; Fischer, R.; Ward, C. Exploring Cultural Differences in Critical Thinking: Is It About My Thinking Style or Is It the Language I Speak? Learn. Individ. Differ. 2010, 20, 604-616. [CrossRef]

24. Sng, B. Cultural Perceptions of Critical Thinking Skills of Asian Theological College Students. J. Adult Theol. Educ. 2011, 8, 153-165. [CrossRef]

25. Wong, L.T.; Wong, W.L.H. The Development of Students' Critical Thinking in EAP Classrooms in Hong Kong. In Teaching and Learning English for Academic Purposes: Current Research and Practices; Nova Science Publishers: New York, NY, USA, 2018; pp. 199-218.

26. Salsali, M.; Tajvidi, M.; Ghiyasvandian, S. Critical Thinking Dispositions of Nursing Students in Asian and Non-Asian Countries: A Literature Review. Glob. J. Health Sci. 2013, 5, 172-178. [CrossRef]

27. King, P.M.; Wood, P.K.; Mines, R.A. Critical Thinking among College and Graduate Students. Rev. High. Educ. 1990, 13, 167-186. [CrossRef]

28. Maneval, R.E.; Filburn, M.J.; Deringer, S.O.; Lum, G.D. Concept Mapping. Does It Improve Critical Thinking Ability in Practical Nursing Students? Nurs. Educ. Res. 2011, 32, 229-233.

29. Zetriuslita, H.J.; Ariawan, R.; Nufus, H. Students' Critical Thinking Ability: Description Based on Academic Level and Gender. J. Educ. Pract. 2016, 7, 154-164.

30. Bers, T.H.; McGowen, M.; Rubin, A. The Disposition to Think Critically Among Community College Students: The California Critical Thinking Dispositions Inventory. J. Gen. Educ. 1996, 45, 197-223.

31. Sedlak, C.A.; Doheny, M.O.; Panthofer, N.; Anaya, E. Critical Thinking in Students' Service-Learning Experiences. Coll. Teach. 2003, 51, 99-103. [CrossRef]

32. Campbell, C.G.; Oswald, B.R. Promoting Critical Thinking through Service Learning: A Home-Visiting Case Study. Teach. Psychol. 2018, 45, 193-199. [CrossRef]

33. Zhang, J.; Chen, B. The Effect of Cooperative Learning on Critical Thinking of Nursing Students in Clinical Practicum: A Quasi-experimental Study. J. Prof. Nurs. 2021, 37, 177-183. [CrossRef]

34. Fong, C.J.; Kim, Y.; Davis, C.W.; Hoang, T.; Kim, Y.W. A Meta-analysis on Critical Thinking and Community College Student Achievement. Think. Skills Creat. 2017, 26, 71-83. [CrossRef]

35. Thinh, P.N. The Intertwined Relationship between Critical Thinking and English Proficiency: Evidence from Vietnam. Int. J. Acad. Res. Educ. Rev. 2018, 6, 22-31. 
36. Mangena, A.; Chabeli, M.M. Strategies to Overcome Obstacles in the Facilitation of Critical Thinking in Nursing Education. Nurse Educ. Today 2005, 25, 291-298. [CrossRef]

37. Manalo, E.; Sheppard, C. How Might Language Affect Critical Thinking Performance? Think. Skills Creat. 2016, 21, 41-49. [CrossRef]

38. Huang, Y.; Ning, C. Enhancing critical thinking in Chinese students in physical education through collaborative learning and visualization. Think. Skills Creat. 2021, 42, 100958. [CrossRef]

39. Liang, W.; Fung, D. Fostering critical thinking in English-as-a-second-language classrooms: Challenges and opportunities. Think. Skills Creat. 2021, 39, 100769. [CrossRef]

40. Liao, Y.H.; Chen, Y.L.; Chen, H.C.; Chang, Y.L. Infusing creative pedagogy into an English as a foreign language classroom: Learning performance, creativity, and motivation. Think. Skills Creat. 2018, 29, 213-223. [CrossRef]

41. Yang, Y.T.; Chang, C.H. Empowering students through digital game authorship: Enhancing concentration, critical thinking, and academic achievement. Comput. Educ. 2013, 68, 334-344. [CrossRef]

42. Yang, Y.; Wang, X. Predicting student translators' performance in machine translation post-editing: Interplay of self-regulation, critical thinking, and motivation. Interact. Learn. Environ. 2020, 1-15. [CrossRef]

43. CSPE. The Hong Kong Polytechnic University-Hong Kong Community College. Committee on Self-financing Post-Secondary Education. 2020. Available online: https://www.cspe.edu.hk/en/institution-details.page?instId=PU/02\# (accessed on 14 May 2021).

44. Facione, N.C.; Facione, P.A. The "California Critical Thinking Skills Test" and the National League for Nursing Accreditation Requirements in Critical Thinking. In The National League for Nursing Accreditation Requirements in Critical Thinking; California Academic Press: Millbrae, CA, USA, 1994. Available online: https:/ / eric.ed.gov / ?id=ED380509 (accessed on 22 December 2021).

45. Insight Assessment. CCTST User Manual and Resource Guide 2021; The California Academic Press: Hermosa Beach, CA, USA, 2021. Available online: https:/ / www.insightassessment.com/article/insight-assessment-user-manuals (accessed on 22 December 2021).

46. Facione, P.A. Experimental Validation and Content Validity; The California Critical Thinking Skills Test-College Level; Technical Report\# 1; California Academic Press: Millbrae, CA, USA, 1990. Available online: https://eric.ed.gov/?id=ED327549 (accessed on 22 December 2021).

47. Facione, P.A.; Facione, N.C. Test Manual: The California Critical Thinking Dispositions Inventory; California Academic Press: Millbrae, CA, USA, 1992.

48. Insight Assessment. CCTDI User Manual and Resource Guide 2021; The California Academic Press: Hermosa Beach, CA, USA, 2021. Available online: https:/ / www.insightassessment.com/article/insight-assessment-user-manuals (accessed on 22 December 2021).

49. Tabachnick, B.G.; Fidell, L.S. Using Multivariate Statistics, 5th ed.; California State University: Long Beach, CA, USA, 2008.

50. Akinwande, M.O.; Dikko, H.G.; Samson, A. Variance Inflation Factor: As a Condition for the Inclusion of Suppressor Variable(s) in Regression Analysis. Open J. Stat. 2015, 5, 754-767. [CrossRef]

51. Roohr, K.C.; Burkander, K. Exploring Critical Thinking as an Outcome for Students Enrolled in Community Colleges. Community Coll. Rev. 2020, 48, 330-351. [CrossRef]

52. Chang, A.M.; Lee, I.; Chau, J.; Lee, D.; Wootton, Y.; Ip, W.Y. Promoting students' critical thinking: The use of videotaped vignettes in a baccalaureate nursing programme. In Further Case Studies of Improving Teaching and Learning from the Action Learning Project; Kember, D., Candlin, S., Yan, L., Eds.; Action Learning Project; The Chinese University of Hong Kong: Hong Kong, China, 2001; pp. 111-117. ISBN 9623672950. Available online: http://cei.hkust.edu.hk/files/public/2d111-118.pdf (accessed on 22 December 2021).

53. Fields, J.B. Assessing the Effectiveness of a Critical Thinking Program to Academic Success of Community College Students. Ph.D. Thesis, Trident University International, Cypress, CA, USA, April 2017.

54. Wangensteen, S.; Johanssoni, S.; Bjorkstrom, M.E.; Nordstrom, G. Critical Thinking Dispositions among Newly Graduated Nurses. J. Adv. Nurs. 2010, 66, 2170-2181. [CrossRef]

55. Huan, Z.; Vickie, L. Critical Thinking Dispositions and Learning Styles of Baccalaureate Nursing Students from China. Nurs. Health Sci. 2008, 10, 175-181.

56. Ip, W.Y.; Lee, D.T.F.; Lee, R.F.K.; Chau, J.P.C.; Wooton, R.S.Y.; Chang, A.M. Disposition Towards Critical Thinking: A Study of Chinese Undergraduate Nursing Students. J. Adv. Nurs. 2000, 32, 84-90. [CrossRef]

57. Li, X.; Guo, X. Comparison of Critical Thinking Skills of Baccalaureate Nursing Students in China. Chin. J. Pract. Nurs. 2004, 21, 61-63.

58. Yeh, M.L.; Chen, H.H. Comparison Affective Dispositions Toward Critical Thinking across Chinese and American Baccalaureate Nursing Students. J. Nurs. Res. 2003, 2, 39-45. [CrossRef]

59. Bycio, P.; Allen, J.S. The California Critical Thinking Skills Test and Business School Performance. Am. J. Bus. Educ. 2009, 2, 1-8. [CrossRef]

60. Facione, P.A. Factors Predictive of CT Skills; The California Critical Thinking Skills Test-College Level; Technical Report\# 2; California Academic Press: Millbrae, CA, USA, 1990.

61. Stone, C.A.; Davidson, L.J.; Evans, J.L.; Hansen, M.A. Validity Evidence for Using a General Critical Thinking Test to Measure Nursing Students' Critical Thinking. Holist. Nurs. Pract. 2001, 15, 65-74. [CrossRef] 
62. Marin, L.M.; Halpern, D.F. Pedagogy for Developing Critical Thinking in Adolescents: Explicit Instruction Produces Greatest Gains. Think. Skills Creat. 2011, 6, 1-13. [CrossRef]

63. Ricketts, J.C. The Efficacy of Leadership Development, Critical Thinking Dispositions, and Student Academic Performance on the Critical Thinking Skills of Selected Youth Leaders. Ph.D. Thesis, University of Florida, Gainesville, FL, USA, 2003.

64. Miller, D.R. Longitudinal Assessment of Critical Thinking in Pharmacy Students. Am. J. Pharm. Educ. 2003, 67, 890. [CrossRef]

65. Profetto-McGrath, J. The Relationship of Critical Thinking Skills and Critical Thinking Dispositions of Baccalaureate Nursing Students. J. Adv. Nurs. 2003, 43, 569-577. [CrossRef] [PubMed] 